acid-1.14 $\mathrm{C}$ dissolved in $9.5 \mathrm{ml}$. of $0.01 M$ potassium hydroxide with a total radioactivity of 35,112 c.p.s.) The plasma-palmitate mixture was added to the blood cells and remainder of the plasma. Fifteen-ml. samples of this suspension were then incubated with slight shaking at $37^{\circ} \mathrm{C}$. in an atmosphere of 5 per cent carbon dioxide-air and in the presence of 1,000 units per sample of both penicillin and streptomycin. Some of the incubations were carried out in the presence of $72 \gamma$ of cestrone or $200 \gamma$ of ethylenediamine tetraacetic acid (added as the sodium salt) per ml. of suspension. After $8 \mathrm{hr}$. the cells were separated and freed from the plasma and the lipids of both were extracted by the method of Delsal ${ }^{\text {. }}$.

Total radioactivity was measured in a flow counter (Nuclear Instruments and Chemical Corporation D.47 Micromil Flow Counter). Total lipids were separated by silicic acid chromatography into six fractions (cholesterol esters, triglycerides, cholesterol, diglycerides, monoglycerides and phospholipids) using a modification $(1,5,10$ and 25 per cent ether in petroleum ether, ether and methanol) of the method described previously ${ }^{1-7}$.

The first 3 fractions were purified by passage through a short alumina column to remove free fatty acids $^{7}$ and the radioactivity of each fraction was measured by the direct plating technique of Entenman et al. ${ }^{8}$.

Under the conditions of the present experiment, at least 10 per cent of the total radioactivity of added palmitic acid was recovered in the blood cells. The radioactivity was found largely in the triglyceride, cholesterol and phospholipid fractions.

In general the glyceride fractions had the highest specific activity although the greatest percentage (more than one-half) of the total activity was in the phospholipid fraction. No significant amount of radioactivity was found in the cholesterol ester fractions. Some evidence was obtained indicating that in the presence of ethylenediamine tetraacetic acid and œestrone the distribution of the radioactivity among the different lipids was altered.

These results will be discussed in greater detail in a subsequent communication.

This work was supported by Contract $A T(04-1)$ $G E N-12$ between the Atomic Energy Commission and the University of California.

Constantinos J. Mrras*

DOROTHY L. FILLERUP

JAMES F. MEAD

Laboratory of Nuclear Medicine and Radiation Biology,

Department of Biophysics and Nuclear Medicine, School of Medicine, University of California, Los Angeles.

- Supported by an International Atomic Energy Agency fellowship. Present address: Experimental Therapeutics Department, Alexandra Hospital, Athens, Greece.

1 Fillerup, D. L. Migliore, J. C., and Mead, J. F., J. Biol. Chem., 233, 98 (1958).

altman, K. I., Watman, R. N., and Solomon, K., Arch. Biochem. Biophys., 33, 169 (1951).

- Marks, P. A., Johnson, A. B., Hirschberg, E., and Banks, J., Ann. N.Y. Acad. Sci., 95,95 (1958)

4 James, A. T., Lovelock, J. E., and Webb, J., Biochem. J., 73, 106 (1959).

Lovelock, J. E., James, A. T., and Rowe, C. E., Biochem. J., 74, $137(1960)$

- Delsal, J. L., Bull. Soc. Chim. Biol., 26, 99 (1944).

'Mead, J. F., and Fillerup, D. L., Proc. Soc. Exp. Biol. Med., 86, 449 (1954).

- Entenman, C., Lerner, S. R., Chaikoff, I. I., and Dauben, W. G., Proc, Sar. Exp. Biol. Med., 70, 364 (1949).

\section{Effect of Castration on Experimental Liver Lesion in Iguana iguana}

To gain an impression of the development of the hormones produced by the ovary in the liver of Iguana iguana in 30 castrated and $\mathbf{3 0}$ mature females a liver lesion was effected by means of the carbon tetrachloride method of Kaufmann. Afterwards the animals were observed for 70 days, the deaths occurring during this period being recorded. Just as in the rat ${ }^{1,2}$, deaths began immediately in the mature group, most animals succumbing in the third week.

In the group of the castrated animals no losses were suffered in the first few weeks. Deaths occurred not before the fourth week with a maximum in the fifth week. In a period of 70 days, 24 of the 30 mature animals died and only 10 of the 30 castrated animals. This significant difference between the death-rates of the two groups suggests that castration is capable of exerting a protective action in the experimental liver lesion and that the hormones provided by the ovary reach development more poorly in the mature than in the castrated animals. This is also suggested by observations that in the case of an equal degree of liver lesion the castrated animals tolerate better the load of experimentally administered ovarian extract and evidently the injected animals develop more rapidly than the mature animals.

These results are in good agreement with the data obtained in the rat, ${ }^{1,2}$ and therefore have a certain general significance. Obviously, the no longer normal liver is seriously damaged by the hormones produced by the ovary, so that the mature animals perish more rapidly and in larger numbers after liver lesions. When the source of these hormones is eliminated by castration, the liver can to a considerable extent be relieved, through which the progress of the disease is prevented.

A. Stolk.

Histological Laboratory,

Free University, Amsterdam.

'Kulcsár, A., and Kulcsár-Gergely, J., Naturwiss., 47, 183 (1960). ${ }^{2}$ Kulcsár-Gergely, J., and Kulcsár, A., J. Pharm. Pharmacol., 12, 312 $(1960)$.

\section{HAMATOLOGY}

\section{Absence of Abnormal Hæmoglobins in Colombian Tunebo Indians}

As examination by paper electrophoresis has been carried out of hæmoglobin from 100 Tunebo Indians from the Santa Librada Mission located at San Luis de Chuscal (Department of Santander, Colombia). This tribe, whom historical and anthropological references consider to be a branch of the large Chibcha Indian group, consists of approximately 2,000 inhabitants spread over 22 small communities along the Rivers Suisiga, Cobaría and Cobugon, tributaries of the River Arauca, situated on the eastern slopes of the Sierra Nevada de Cocuy, between lat. $6^{\circ} 15^{\prime}$ and $7^{\circ} 10^{\prime} \mathrm{N}$., and long. $71^{\circ} 50^{\prime}$ and $72^{\circ} 20^{\prime} \mathrm{W}$. All the individuals studied were adults, apparently normal. Both sexes were proportionally represented and the blood was drawn only from subjects not closely related. 